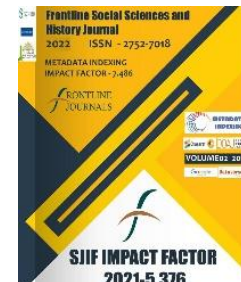
2021-5.376

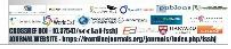

Journal Website: https://frontlinejournal s.org/journals/index.ph $\mathrm{p} /$ fsshj

Copyright: Original content from this work may be used under the terms of the creative commons attributes 4.0 licence.
Research Article

\section{LINGUISTIC PRAGMATICS OF PHRASEOLOGICAL IDIOMS}

Submission Date: January 11, 2022, Accepted Date: January 21, 2022,

Published Date: January 31, 2022

Crossref doi: https://doi.org/10.37547/social-fsshj-02-01-03

\section{Dildora Shuhratovna Abdullayeva}

Lecturer of Namangan State University, Uzbekistan

\title{
Abstract
}
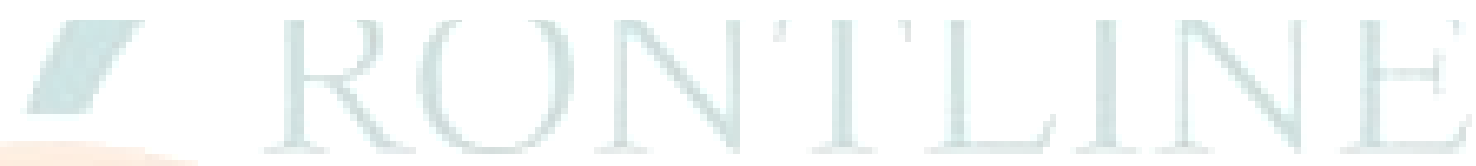

In this article we will discuss Pragmatical meanings of phraseological units and difference between informema and pragmemas. The main purpose of the article is to define and explain the meaning of this term. The research explored comperative method in both finding theory and suitable examples. The finding of the research shows the impact of pragmatics in real life conversation. While socializing people really need pragmatic meaning for understanding speaker's attitude, feeling and thoughts. Theoretical contributions and practical are presented by phraseological units, idioms and authentic dialogues, and drew a conclusion, opposite meaning of semantics argued as pragmatics.

\section{KEYWORDS}

Phraseological units, pragmatic meaning, informema, antropocentric, speech portrait of a person, speech act. 


\section{INTRODUCTION}

As is well known, the main ways to achieve rich, expressive and emotional speech is a reasonable use of different phraseological expressions, idioms, proverbs, sayings, colorful expressions.

The term phraseology was introduced by Swiss linguist Charles Bally. Bally was the first who systematized the combination of the words in his book "Studies of the Stylistics" and "French Stylistics". Ch. Bally explored the sphere of linguistics and phraseology in the French language, however, his attempt to systematize and classify phraseological units led to the series of other studies in the phraseological sphere in other languages, including English. After Bally many linguists began to advance their opinions and give their own definition of the term "phraseology". Altenburg stated that than productive or rule-governed side of language, involving various kinds of composite units and pre-patterned expressions such as idioms, fixed phrases and collocations.

Even today this sphere is in the focus of many researches. So, in his book "The Course of the Modern English Phraseology", A.V. Kunin investigated a wide range of phraseological characteristics, methods of their studies, phraseological system and presents classification of idiomatic expressions according to their features (1990). Komissarov contributed in this field by studying the methods of translating phraseological units (2004).

\section{Methods}

The methods of investigation that are used in this work are linguopragmatical conceptual analysis including cognitive mapping and conceptual blending. Methodological basis of the given article is works of such scholars as G. Lakoff , and M. Johnson, Kubryakova, V. Z. Demynkov; Chudinov, Kunin and many others. Phraseological units are considerable parts of any language. Therefore, they are studied by plenty of scholars. For example, Russian scholars V. V. Vinogradov, A. I. Smidnitoski, H.N. Asomova and Uzbek scholars Sh. Rahmatullayev, A. E. Mamatov, B. Yo`ldhoshev conducted a research on this sphere of linguistics. Their works and researches play significant role in the development of phraseology. Even nowadays, this field of linguistics attracts great many of 
scholars' attention. A. B. Pittman defines phraseological units in his works as a group words in a fixed order that is different from the meaning of each word understood on its own (Urantaeve N, 2017). In fact, idioms can never be translated into another language word for word. Otherwise, they lose their semantic meaning. For instance, if we translate the idiom "Lend an ear" into Uzbek word by word, it means "qulog ini qarzga bermoq". Because, the word "lend" means to let someone borrow something that belongs to you for a short time. However, in this work you can see this kind of phraseological units with its equivalent in Uzbek language.

The modern linguistics is based on the principle of anthropocentric paradigm, which contains "human factor" in the study of language. This paradigm puts forward the new approaches to the researches of language which are implemented within a number of new desciplines, such as cognitive linguistics, text linguistics, linguoculturology, linguopersonalogy, linguopragmatics and etc. These branches of linguistics need to be studied separately, indeed, the pragmatic meaning is also plays an important role as semantic one while overcoming pragmatic failure in the act of speech.

We admit that, in many cases, we deal with similar logical and semantic patterns in all investigated languages because of the existence of the same human universal spirit, of a resembling ontological experience, of a common Europe identity. We could also assert, based on the previously, analyzed descriptive material, that there are unique phraseological units in the culture and mentality of each community, determined by different economic, social, historical and psychological aspects. Since phraseology in comparative linguo-cultural studies is still relatively young field of research, much more corpora are necessary to learn and understand the national spirit of the certain ethnic group through cultural concepts.. this is one of the first attempts when these languagesUzbek, English and Russian have been compared. Therefore, the prospects of further investigation are connected with the comparison of phraseological units in the anthropocentric paradigm expanding the study by the large group of phraseological idioms. The comparison will be continued, and the conclusions of the proposed research have a premature character. As an 
example: "wallflower" translating word by word the meaning is flower is hung on the wallinformema.

Girl who was not invited to dance (in a party)pragmema.

We can say that phraseological ints are extremely important parts of linguistics in any language. Additionally, the usage of idioms is so common in the field of translation since it has more benefits for translators and interpreters. But while translating them from one language into another should be careful about their meaning and pay attention to find the most suitable equivalent of these idioms instead of translating them word for word.

Speech act theory is now receiving great attention and valid theoretical proposals from cognitive linguistics. In this article we will try to describe possible approaches to the description of pragmalinguistics as a system of science of Linguistics and connection with semantics, tasks and practical role of pragmemas.

By concluding all the views, we can point out the following aspects and approaches:
The relations between a sign and its users (Morris, 1978)

- Contextual conditionally, language usage, language in the context (Susov, 1985)

- $\quad$ Speech impact on the addressee, the factors influencing successful and effective communication (Ksiloya, 1978)

- Interpretive aspects of speech communication (Arutyunova, 1989) Language as a tool of a purposeful communicative activity (Grays, 1985) The problem of mutual understanding and appropriateness of language use (Dijk. T. A. van, 1977)

Linguistics in pragmatics: the study of features of language use related to speaker`s knowledge of the structure and expressive resource of the language itself rather than of the social context (Oxford Living Dictionaries).

\section{Findings}

Linguistics pragmatics do not have a clear form. It includes a set of issues related to speaker and the listener, their interaction in the speech process. Linguistics pragmatic aspects, the 
relationship between the speaker and the listener, the interaction of participants in the speech act, and their influence on ethical emotions. The problems of linguistics does not have their own interpretation. As a part of Pragmatics and a part of the linguistic science, the word pragmaling seems to be a natural thing to say about the category of units. There are two pragmalingvistic units: 1 . Informema. 2. Pragmema

Pragmalingvistic units are directly affected by language units and functional language areas. The pragmats come into opposition with the information-gathering function. Pragmembers are always pragmatic information carriers.

The phraseological idioms are determined by social and political aspects, traditions, customs, cultural values which create similar thematic domains in all investigated languages. The cultural concepts in the research will be described within a broader anthropocentric paradigm since it includes the cultural dimension; and its central assumption is that every language, especially its figurative meanings is connected with the reflection of the world-view shared by the linguistic knowledge about the reality. Cultural concepts in anthropocentric phraseology of the proposed research are abstract notions such as, for instance, intellectual ability, emotional and expressive aspects, picture in a culturally specific way. Both concepts proper and sub-concepts are involved. It is noteworthy indeed that "their specificity is implemented mostly at the cognitive not the semantic level because cultural background refers to information that is most difficult to formalize, as it connected with semantics in a very indirect and still unexplored way" as, for instance, in the paradigam the traits of character with the positive meaning in the sub-concept smart, capable: Uzbek.: kalla bor 1)someone is very smart, capable; 2)to do something after proper consideration: Mening ham kallam bor!; Rus.: голова на плечах; compare: с головой: -У тебя есть погоны и голова на плечах- иди и зарабатывай, - сказал в интервью сотрудникам института один московский милиционер; Eng.: a bright chap (girl); a person with the head on his shoulders; to use one`s head (loaf) when doing something Matthew, the eldest, is quite a bright chap and Emma, the next one age-wise, is all right but learning the recorder. 
The mentioned before subgroup also involves such feature of character as capability: Uzbek: qo'li gul:- Qo'li gul usta Umar yana bir bor o`z mahoratini namoyon etdi; Rus: золотые руки: $\mathrm{y}$ него золотые руки! Хотите/ он и вам такую машину сделает? Молодец! Золотые руки. Любо-дорого глядеть/ кода он за что-нибудь берётся, мастер на все руки: Он и хормейстер, и концертмейстер, и режиссёр драмкружка; играл на всех инструментах и в изобразительном искусстве разбирался, словом, одарённая личность, мастер на все руки, энтузиаст своего дела, сумел увлечь и других; Eng.: somebody is good hand at any job; somebody can do anything with his hands. The phraseological units of that subgroup are common to all investigated languages because of the same factors of logical and psychological nature.

We can see further examples in the table below which shows English idioms with appropriate equivalence.

\section{Table1}

\begin{tabular}{|l|l|}
\hline English idioms & Equivalents in Uzbek languages \\
\hline To take a mountain out of a molehill & Pashshadan fil yasamoq \\
\hline A piece of cake & Oddiy masala \\
\hline Care killed the cat & Ish qaritmaydi, gam qaritadi \\
\hline Many hands make light work & Ko`pdan quyon qochib qutulmas \\
\hline
\end{tabular}

The most important function of any language unit, including phraseological, is the pragmatic function, i.e. purposeful impact of the language mark on the addressee. The section focuses on the pragmatic aspect of the functioning of phraseological units, the mastery of which is prerequisite for effective communication.
According to the principle of anthropocentrism, the main factor regulating the development and functioning of phraseological units is the human factor in the language. Human speech becomes a point of reference in the analysis of the functional and pragmatic aspects of phraseological units. 
(ISSN - 2752-7018)

VOLUME 02 ISSUE 01 Pages: 19-27

SJIF IMPACT FACTOR (2021: $5 \cdot 376$ )

OCLC - 1276789625 METADATA IF - 7.569

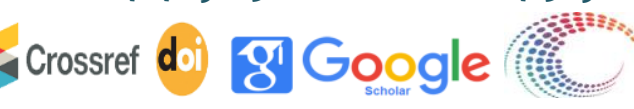

InDExing

Publisher: Frontline Journals

This section discusses the pragmatic potential of simple structured phraseological units. Their functional significance is beyond doubt, since they have such pragmatically relevant properties as the complexity of the semantic structure and the ability to associate. Idiom, as a rule, are used in cases where the subject of speech is necessary to express an emotional relationship to the subject of thought, to produce a certain pragmatic effects on the recipient. The term "pragmatics" was introduced into scientific use by one of the founders of semiotics - the general theory of signs -Ch. Morris, who divided semiotics into semantics , syntactic and pragmatics, understanding the latter as a teaching about attitudes signs to their interpreters, that is, to those who use sign systems. (Ariel M. 2010)

Thus, pragmatics studies the behavior of signs in real communication process. If semantics shows what a person says, what statement means, then a pragmatist seeks to reveal the conditions and the purpose for which person speaks in this case. The pragmatic potential of language and communication, according to N.I. Formanovskaya is associated with the attitude of a person to linguistic signs, with the expression of his attitudes, assessments, emotions, and intensions during the production (and perception) of speech actions in statements and discourses.

According to R.S.Stolnaker, formal pragmatics can become no less exact science than modern logical syntax or logical semantics, as it "allows you to chart a new approach to the study of some philosophical problems that cannot be solved within the framework of traditional formal semantics, and clarifies the relation of logic and formal semantics to the study of natural language". If the syntax deals with the study of the sentence, and the semantics examine the propositions, the pragmatist studies the speech acts and the context in which they are implemented. According to the theory of communication, any text has a pragmatic setting. A textually finished piece of text, as a context, is a product of language communication. In the context all attitudes and intensions implemented by the speaker in a speech strategy are most clearly manifested. The fact that the pragmatic information formulated in the text can be represented by both verbal and non-verbal means allows us to introduce the concept of communicativepragmatic context. In this kind of context, one can single out parameters related to the quality of the utterance, the scope of the language, the relations between the communicants, etc. The meaning of phraseological units is revealed in a pragmatic context. The context is in the relation of complementarity to another pragmatic concept for the pragmatic- the speech act. According to G.Austin, a speech act is a type of action, and when analyzing it, essentially the same categories are used that are necessary to characterize and evaluate any action, namely: purpose, method, means, result, conditions, etc. The subject of the speech 
(ISSN - 2752-7018)

VOLUME 02 ISSUE 01 Pages: 19-27

SJIF IMPACT FACTOR (2021: $5 \cdot 376$ )

OCLC - 1276789625 METADATA IF - 7.569

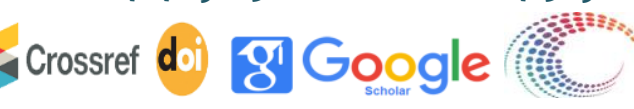

InDexunc 5 . WorldCat

Publisher: Frontline Journals

act-the speaker - produces a statement designed to be perceived by the addressee - the listener. The statement acts simultaneously as a product of the speech act, and as a tool to achieve a specific goal. Depending on the circumstances or on the conditions in which the speech act is performed, he can either achieve the goal and thus be successful, or not achieve it. The interaction of the speech act and the context is the main core of pragmatic research, and the formulation of the rules of this interaction is its main task. Pragmatic interests begin where the connection between the context and the speech act is as intense as possible. In recent years, interest in issues related to the functioning of phraseological units in various communicative conditions has increased. A special place here takes a communicative and pragmatic study of phraseology, aimed at the study of speech activity using phraseological units. Speech activity was considered as one of the forms of life. It was again realized that "not only language paints a picture of the world..., but life also provides the key to understanding many phenomenaof language and speech. This direction of relations became decisive for pragmatic research. The pragmatic function of phraseological units is a targeted impact on the addressee. Being implemented in context, it is closely related to the stylistic function of phraseological units. Based on the communicative and pragmatic attitudes of the texts under study, the main pragmatic parameters can be considered as expressiveness, conceptuality and subtextual information.

In short, the modern linguistics is based on the principle of anthropocentric paradigm, which contains "human factor" in the study of language. This paradigm puts forward the new approaches to the research of language which are implemented within a number of new desciplines, such as cognitive linguistics, text linguistics, linguoculturology, linguopersonology, linguopragmatics and etc. These branches of linguistics need to be studied separately, indeed. The pragmatic meaning is also plays an important role as semantic one while overcoming pragmatic failure in the act of speech.

\section{Conclusion}

To conclude, we admit that, in many cases, we deal with similar logical and semantic patterns in all investigated language because of the existence of the same human universal spirit, of a resembling ontological experience, of a common European identity. We could also assert, on the basis of the previously analyzed descriptive material, that there are unique phraseological units in the cultural and mentality of each community, determined by different economic, social, historical and psychological aspects. Since phraseology in comparative linguo-cultural studies is still relatively young field of research, much more corpora are necessary to learn and understand the national spirit of the certain ethnic 
group through cultural concepts. This is one of the first attempts when these languages- Uzbek, English, Russian, have been compared. Therefore, the prospects of further investigation relate to the comparison of phraseological units in the anthropocentric paradigm expanding the study by the large group of phraseological idioms. The comparison will be continued, and the conclusions of the proposed research have a premature character.

\section{References}

1. Ariel M. Research survey in linguistics. -Cambridge University Press. 2010

2. Ashurova D.U. Text of linguistics.- Tashkent: Tashkent Tashakkur qanoti, 2012

3. Abdullayeva D.Sh, Rafikova. F.A \& et al(2019). The Study of Phraseological units under the heading of linguopragmatics.

ISJTheoretical\&Applied Science,12(80),262-266

4. Abdullayeva D.Sh(2021). The Importance of Dictionary Instructions in Formulating Pragmatic and Language Competency of Learners. The American Journal of Social Science and Educational Innovations, 3(01) 268-274.

5. Abdullayeva D.Sh(2021). Linguopragmatic features of Phraseological Units in ESL class. International scientific-practical conference The 2nd
International Conference on XXI century skills in Language Teaching and Learning.14-18p 